\title{
VIABILITAS DAN PRODUKTIVITAS SELULOSA DARI INOKULUM KERING Acetobacter xylinum DENGAN SUBSTRAT PEMBAWA BERUPA SERBUK KELAPA PARUT DAN SERBUK AMPAS KELAPA PARUT
}

\author{
Amalia Fitri Andriani \\ Penulis Adalah Dosen Jurusan Biologi, Fakultas Saintek,UIN MMI Malang
}

\begin{abstract}
ABSTRAK
Inokulum nata yang berisi kultur Acetobacter xylinum, pada umumnya tersedia dalam bentuk agar slant atau bentuk kultur cair dalam medium air kelapa. Bentuk inokulum tersebut membutuhkan perlakuan khusus dan mahal. Seiring dengan penigkatan kebutuhan inokulum nata de coco, maka bentuk inokulum dikembangkan agar lebih praktis, mudah perlakuannya, penyimpanan dan aman dalam transportasi. Penelitian ini bertujuan untuk mengetahui kemungkinan penyediaan inokulum kering nata de coco dengan substrat pembawa berupa serbuk kelapa parut dan serbuk ampas kelapa parut. Inokulum kering dibuat dengan menginokulasikan kultur cair A. xylinum ke dalam serbuk kelapa parut kering dan serbuk ampas kelapa parut kering kemudian dilakukan pengeringan dengan inkubator dengan suhu $30^{\circ} \mathrm{C}$ dan $40^{\circ} \mathrm{C}$. Inokulum dalam bentuk serbuk kering dengan substrat pembawa berupa serbuk kelapa parut dan serbuk ampas kelapa parut dapat dibuat dengan pengeringan suhu $30^{\circ} \mathrm{C}$ selama 30 jam dengan perbandingan substrat pembawa : inokulum cair sebanyak 1:2. Inokulum kering dengan substrat pembawa berupa serbuk kelapa parut memiliki kadar air $3,25 \%$, vabilitas $1,0 \times 10^{7}$ sel/g dan produktivitas selulosa 5,55 g/L. Inokulum kering dengan substrat pembawa berupa serbuk ampas kelapa memiliki kadar air 2,98\%, viabilitas 4,2 $\times 10^{5}$ sel/g dan produktivitas selulosanya sebasar 4,92 g/L. Produktivitas selulosa inokulum kering tersebut setara dengan $80 \%$ produktivitas selulosa hasil inokulum cair dari isolat A. xylinum asal.
\end{abstract}

Kata kunci : nata de coco, inokulum kering, Acetobacter xylinum, selulosa bakteri, substrat pembawa

\section{PENDAHULUAN}

Di Indonesia selulosa bakteri pada umumnya dimanfaatkan dalam industri makanan yang dikenal dalam istilah nata, antara lain nata de coco karena menggunakan air kelapa sebagai substrat fermentasinya. Nata de coco merupakan lapisan selulosa yang terbentuk pada permukaan air kelapa yang dihasilkan dari proses fermentasi oleh bakteri Acetobacter xylinum. Kandungan gula (dalam bentuk glukosa) yang terdapat dalam air kelapa diubah menjadi lapisan selulosa ekstraseluler oleh bakteri tersebut (Fardiaz, 1992 ; Sudirjo, 1996).

Perkembangan penelitian terhadap selulosa bakteri menghasilkan pemanfaatan selulosa bakteri yang lebih luas. Saat ini selulosa bakteri selain sebagai produk makanan, juga merupakan salah satu sumber alternatif penyediaan selulosa yang dapat memenuhi kebutuhan selulosa untuk aplikasi diberbagai bidang industri seperti pembuatan kertas, membrane akustik, obat-obatan dan kosmetik (Serafica, 1997).

Terdapat beberapa genera bakteri yang diketahui dapat mesintesis selulosa namun hanya spesies dari Acetobacter yang dapat memproduksi selulosa dalam jumlah yang cukup untuk kepentingan komersial. Selulosa bakteri dapat dihasilkan antara lain oleh A. xylinum, $A$. pasteurianus dan A. acetigenus yang ditumbuhkan pada medium kultur yang mengandung sumber karbon dan nitrogen (Fardiaz, 1992 ; Sudirjo, 1996).

Pengembangan disain bioreaktor dan produksi yang ekonomis, harga bahan baku substrat dan tenaga kerja yang murah serta aplikasi produk yang bernilai tinggi akan menentukan masa depan industri selulosa bakteri (Serafica, 1997). Produksi selulosa bakteri dari nata de coco yang memanfaatkan limbah berupa air kelapa sebagai substrat fermentasi memiliki biaya produksi yang relatif lebih murah dan penggunaan tenaga kerja berbiaya rendah.

Di Indonesia, produksi nata de coco yang dikerjakan baik oleh industri rumah tangga maupun industry berskala besar pada umumnya menggunakan inokulum (starter) dalam bentuk cair. Inokulum tersebut membutuhkan pemeliharaan selama penyimpanan. Pada saat akan digunakan diperlukan beberapa tahapan persiapan untuk menjadi inokulum siap pakai. Pemeliharaan inokulum dengan pemindahan kultur yang berulang-ulang dapat menyebabkan penurunan kemampuan produktivitas inokulum (Parton dan Willis, 1990).

Inokulum (starter) bakteri A. xylinum untuk nata de coco yang tersedia di Indonesia pada umumnya disimpan dan dijual dalam bentuk kultur 
pada agar miring atau kultur cair dengan medium air kelapa. Penanganan dan pemeliharaan inokulum tersebut relatif sulit dan mahal. Inokulum bakteri $A$. xylinum dalam bentuk yang lebih praktis dan relatif lebih mudah ditangani dalam produksi nata serta mudah dalam penyimpanan dan transportasi belum tersedia (Waspodo et.al., 2000).

Salah satu alternatif yang dapat ditempuh untuk kemudahan produksi tanpa menurunkan kualitas dan kuantitas nata maupun selulosa bakteri yang dihasilkan adalah dengan penyediaan inokulum dalam bentuk serbuk kering. Inokulum tersebut dibuat dari inokulum dalam kultur cair yang dicampur dengan substrat pembawa lalu dilakukan proses pengeringan sehingga diperoleh inokulum dalam bentuk serbuk kering. Substrat pembawa yang akan digunakan berasal dariolahan buah kelapa yaitu serbuk kelapa parut kering dan serbuk ampas kelapa parut. Penggunaan produk olahan tersebut dapat meningkatkan nilai ekonomi dan pemanfaatan produksi kelapa di Indonesia yang memiliki areal perkebunan kelapa paling luas (Palungkun, 2004).

\section{BAHAN DAN CARA KERJA}

Bahan

Bahan yang digunakan adalah inokulum Acetobacter xylinum dalam bentuk agar miring. Medium pemeliharaan, enumerasi dan produksi yaitu medium dari air kelapa, $\left(\mathrm{NH}_{4}\right)_{2} \mathrm{HPO}_{4} \quad 0,1 \%$ (b/v), gula pasir $10 \%(\mathrm{~b} / \mathrm{v})$ dan asam asetat glasial. Bahan sebagai substrat pembawa adalah serbuk kelapa dan ampas yang diolah dari endosperm kelapa tua. Bahan untuk mencuci lapisan selulosa adalah larutan $\mathrm{NaOH} 2 \%(\mathrm{~b} / \mathrm{v})$.

Cara kerja

Pembuatan medium air kelapa (modifikasi dari Waspodo et al.,2000).
Sebanyak 1 liter air kelapa disaring menggunakan kain saring kemudian direbus hingga hampir mendidih. Rebusan air kelapa yang telah agak dingin kemudian ditambahi $10 \%$ (b/v) Sukrosa dan $\left(\mathrm{NH}_{4}\right)_{2} \mathrm{HPO}_{4} 0,1 \%(\mathrm{~b} / \mathrm{v})$. Setelah suhu medium sama dengan suhu ruang maka ditambahkan asam asetat glacial untuk menyesuaikan $\mathrm{pH}$ medium hingga mencapai pH 5.

Pembuatan substrat pembawa berupa serbuk kelapa dan serbuk ampas kelapa (Palungkun, 2004)

Pembuatan substrat pembawa dimulai dengan memisahkan kelapa dari testanya. Kelapa bagian endospermnya dibelah kemudian dikukus selama 15 menit. Kelapa diparut dengan alat parut manual. Serbuk kelapa dibuat dengan mengeringkan hasil parutan didalam oven dengan suhu $70^{\circ} \mathrm{C}$ Selama 1,5 jam kemudian dibender selama 1 menit. Cara yang sama dilakukan untuk membuat serbuk ampas kelapa namun sebelum dikeringkan hasil parutan terlebih dahulu ditambah air sebanyak dua kali berat hasil parutan lalu diperas santannya. Dalam penelitian ini serbuk kelapa parut dan serbuk ampas kelapa digunakan sebagai substrat pengikat dan disebut substrat pembawa.

\section{Pembuatan inokulum kering}

Pembuatan inokulum dimulai dengan optimasi suhu inkubasi kemudian dilanjutkan dengan optimasi perbandingan substrat pembawa dengan inokulum cair (modifikasi dari Waspodo et al., 2000).

Serbuk kelapa parut atau serbuk ampas kelapa diinokulasi dengan kultur cair, kemudian diinkubasi selama 12 jam di dalam inkubator dengan suhu $30^{\circ} \mathrm{C}$ dan $40^{\circ} \mathrm{C}$.

Tabel 1 : Perbandingan substrat pembawa dengan inokulum cair :

\begin{tabular}{ccc}
\hline Perbandingan & $\begin{array}{c}\text { Serbuk Kelapa atau Serbuk } \\
\text { Ampas Kelapa }(\mathrm{g})\end{array}$ & Inokulum Cair (mL) \\
\hline $1: 1$ & 5 & 5 \\
\hline $1: 2$ & 5 & 10 \\
\hline $2: 1$ & 5 & 2,5 \\
\hline
\end{tabular}

Wadah inokulum selama proses pengeringan berupa kotak berukuran 10 x 5 x 2,5 cm yang dilapisi aluminium foil dan ditutup dengan kertas. Setelah proses pengeringan, inokulum dengan masing-masing perlakuan diuji viabilitas dan produktivitas selulosanya serta diukur kadar airnya. Perlakuan suhu dan formula perbandingan dengan hasil yang terbaik digunakan untuk optimasi waktu pengeringan.

\section{Pengujian viabilitas inokulum}

Viabilitas inokulum diuji dengan cara menumbuhkan inokulum pada media padat melalui pengenceran bertingkat untuk melihat populasi bakteri tersebut dengan cara menghitung jumlah sel yang hidup.

\section{Pengujian produktivitas selulosa}

Inokulum kering juga diuji untuk mengetahui produktivitas selulosanya. Inokulum kering sebanyak $10 \%(\mathrm{~b} / \mathrm{v})$ diinokulasikan ke dalam medium cair dan diinkubasi pada suhu $28^{\circ} \mathrm{C}$ selama 7 hari. Pemanenan dilakukan untuk mengetahui produktivitas nata yang dihasilkan. Lapisan nata yang hasil panen kemudian dicuci dan direndam dengan $\mathrm{NaOH} 2 \%$. Setelah itu dilakukan 
pengurangan kadar air dengan menarik air dari lapisan nata menggunakan penyaring Buchner yang terhubung dengan pompa vakum. Lapisan nata selanjutnya dikeringkan dengan menggunakan oven $60-70^{\circ} \mathrm{C}$ selama 24 jam. Lapisan nata kering ditimbang untuk mengetahui berat kering seluosa dalam perhitungan produktivitas selulosa hasil inokulum kering.

\section{HASIL DAN PEMBAHASAN}

A. Optimasi suhu pengeringan inokulum

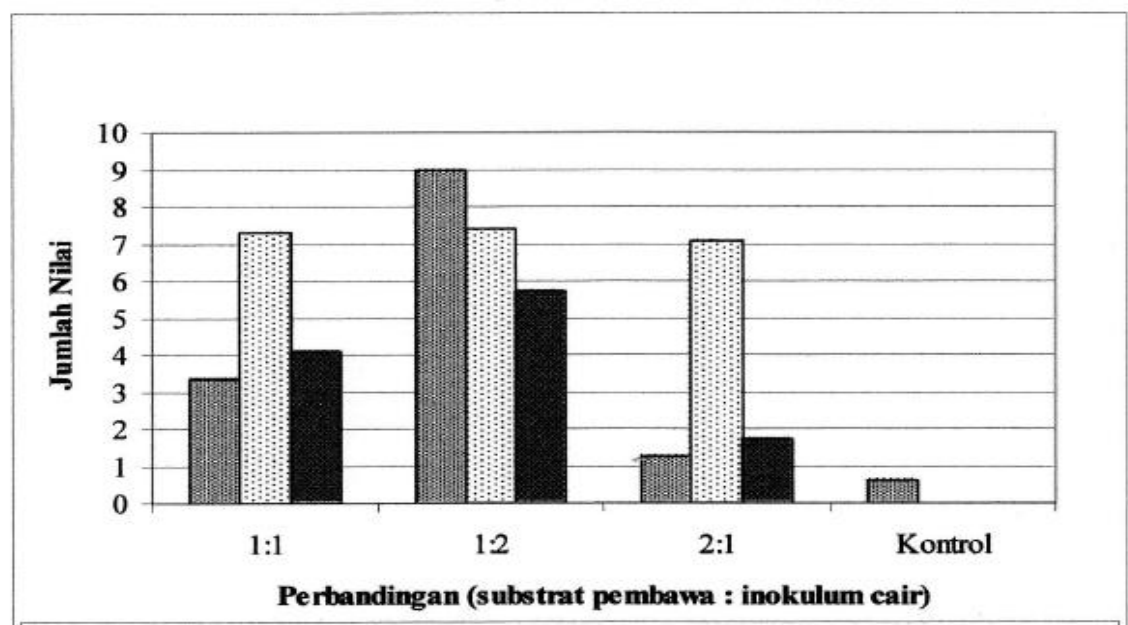

⿴囗十 Kadar Air Inokulum $\boxminus$ Viabilitas (Log Jumlah seV/mL) Produktivitas selulosa (g/L)

Gambar IV.8. Diagram nilai kadar air dan viabilitas inokulum hasil optimisasi perbandingan substrat pembawa berupa serbuk kelapa parut kering dengan inokulum cair serta produktivitas selulosanya. Suhu pengeringan $30^{\circ} \mathrm{C}$ selama $12 \mathrm{jam}$. Kontrol berupa serbuk kelapa parut kering tanpa inokulum.

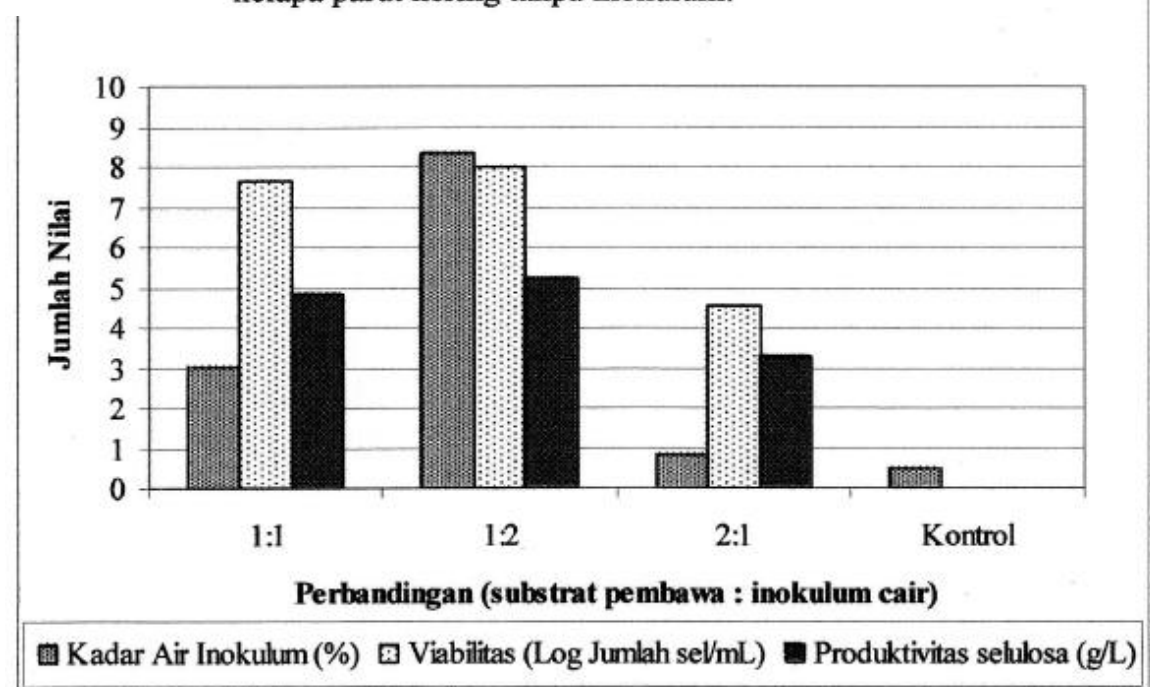

Gambå IV.9. Diagram nilai kadar air dan viabilitas inokulum hasil optimisasi perbandingan substrat pembawa berupa serbuk ampas kelapa parut kering dengan inokulum cair serta produktivitas selulosanya. Suhu pengeringan $30^{\circ} \mathrm{C}$ selama 12 jam. Kontrol berupa serbuk ampas kelapa parut kering tanpa inokulum.

Pengeringan inokulum dilakukan pada suhu $30^{\circ} \mathrm{C}$ dan $40^{\circ} \mathrm{C}$. Suhu tersebut diacu dari penelitian Waspodo et.al. (2000). Suhu tersebut masih berada pada rentang suhu yang memungkinkan $A$. xylinum tetap bertahan hidup meskipun tidak mengalami peningkatan pertumbuhan (Lapuz et.al., 1967).
Hasil optimasi pengeringan pada suhu $30^{\circ}$ C selama 12 jam menunjukkan rata-rata viabilitas sel inokulum sebesar $1,87 \times 10^{7} \mathrm{sel} / \mathrm{g}$, rata-rata produktivitas nata $410,93 \mathrm{~g} / \mathrm{L}$ dan produktivitas selulosa 3,85 g/L untuk substrat pembawa berupa serbuk kelapa parut kering. Pada inokulum dengan 
substrat pembawa berupa ampas kelapa parut kering, rata-rata viabilitas sel inokulum sebesar $4,87 \times 10^{7}$ sel/g, rata-rata produktivitas nata $412,64 \mathrm{~g} / \mathrm{L}$ dan produktivitas selulosa $4,44 \mathrm{~g} / \mathrm{L}$. pada suhu $40^{\circ} \mathrm{C}$, rata-rata viabilitas sel $5,21 \times 10^{6} \mathrm{sel} / \mathrm{g}$ untuk serbuk kelapa parut dan $1,67 \times 10^{6} \mathrm{sel} / \mathrm{g}$ untuk serbuk ampas kelapa parut.

Inokulum hasil pengeringan pada suhu $40^{\circ}$ C masih memiliki viabilitas namun mengalami kehilangan kemampuan dalam menghasilkan selulosa. Kemampuan kondisi tersebut dapat diakibatkan karena adanya perubahan ekspresi fenotipik sel A. xylinum sebagai repson terhadap kondisi lingkungan yitu pengeringan suhu $40^{\circ} \mathrm{C}$. Menurut Serafica (1997), galur A. xylinum memiliki kecenderungan untuk mudah mengalami perubahan ekspresi fenotipik menjadi sel-sel yang tidak memproduksi selulosa $\left(\mathrm{Cel}^{-}\right)$. Seluruh sampel fermentasi yang menggunakan inokulum tersebut tidak menghasilkan nata. Optimasi pada suhu $30^{\circ} \mathrm{C}$ menghasilkan inokulum yang viabel dan masih memiliki kemampuan dalam memproduksi selulosa karena kemungkinan sel-sel A. xylinum tidak berpengaruh kondisinya akibat pengeringan pada suhu $30^{\circ} \mathrm{C}$ tersebut.

Pada optimisasi perbandingan substrat pembawa berupa serbuk kelapa parut kering dan serbuk ampas kelapa parut kering, inokulum yang dihasilkan masih memiliki viabilitas dan tingkat produktivitas selulosa. Viabilitas sel yang diperoleh dari substrat serbuk kelapa parut kering diperoleh dari perbandingan substrat pembawa dan inokulum cair 1:2 yaitu $2,4 \times 10^{7} \mathrm{sel} / \mathrm{g}$ dengan kadar air inokulum yang dihasilkan juga paling tinggi yaitu $8,99 \%$. Viabilitas sel yang diperoleh dari substrat serbuk ampas kelapa parut kering juga diperoleh dari perbandingan substat pembawa dan inokulum cair $1: 2$ yaitu $1,0 \times 10^{8} \mathrm{sel} / \mathrm{g}$ dengan kadar air inokulum yang dihasilkan juga paling tinggi yaitu $8,35 \%$.

Meskipun viabilitas inokulum dari setiap perlakuan relatif sama, namun kemampuan sel dalam memproduksi selulosa mengalami perbedaan yang cukup besar. Hal tersebut menunjukkan bahwa meskipun sel bersifat viabel, namun sel dapat kehilangan kemampuan dalam memproduksi selulosa.

Faktor lingkungan yang kurang mendukung aktivitas sel (kadar air yang rendah), diperkirakan dapat mempengaruhi kemampuan produksi selulosa. Hal tersebut dapat terlihat pada hasil perlakuan perbandingan substrat pembawa berupa serbuk kelapa kering dan inokulum cair 2:1 yang memiliki kadar air $1,26 \%$ dan produksi selulosa terendah $(1,72 \mathrm{~g} / \mathrm{L})$. Begitu pula dengan hasil perlakuan perbandingan substrat pembawa berupa serbuk ampas kelapa kering dan inokulum cair 2:1 yang memiliki kadar air 0,85 \% dan produksi selulosa terendah $(3,27 \mathrm{~g} / \mathrm{L})$.

B.Optimasi waktu pengeringan

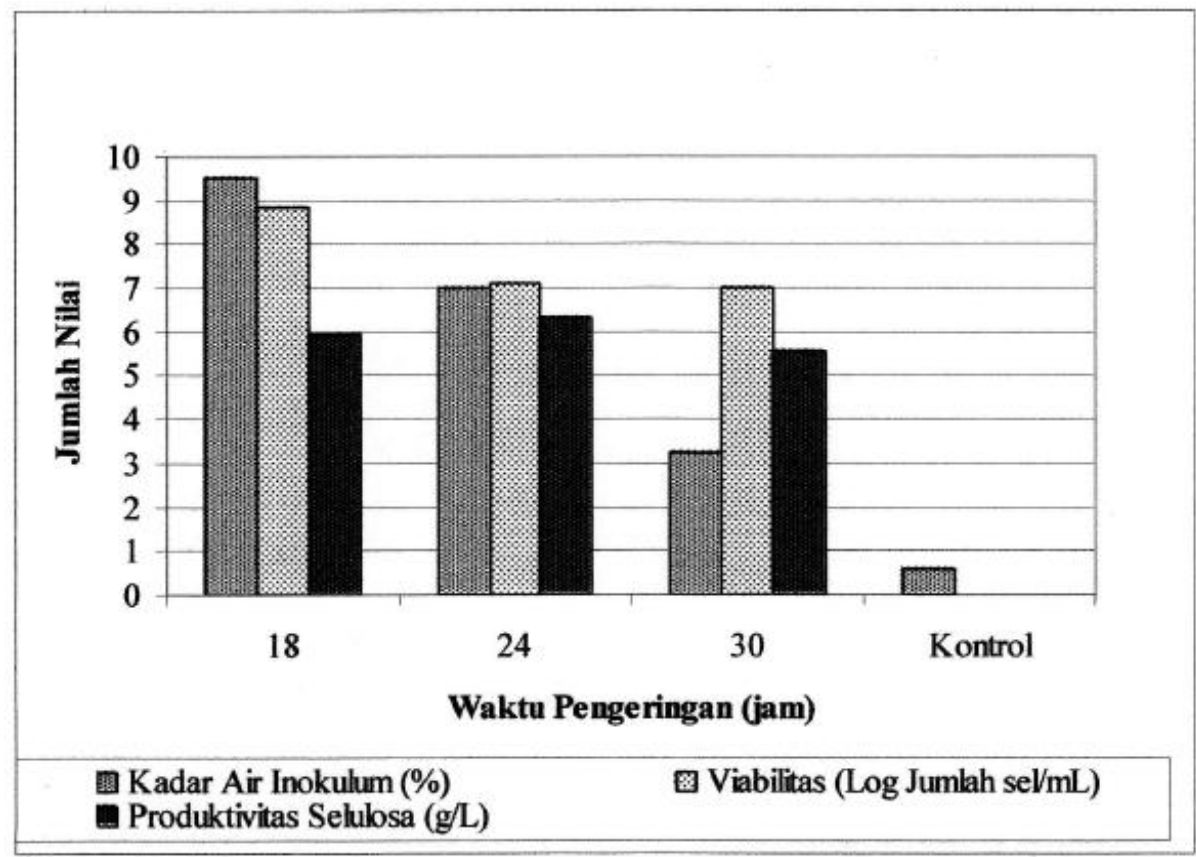

Gambar IV.10. Diagram nilai kadar air dan viabilitas inokulum hasil optimisasi waktu pegeringan inokulum dengan substrat pembawa berupa serbuk kelapa parut kering serta produktivitas selulosanya. Suhu pengeringan $30^{\circ} \mathrm{C}$ dan perbandingan substrat pembawa $1: 2$. Kontrol berupa serbuk kelapa parut kering tanpa inokulum. 


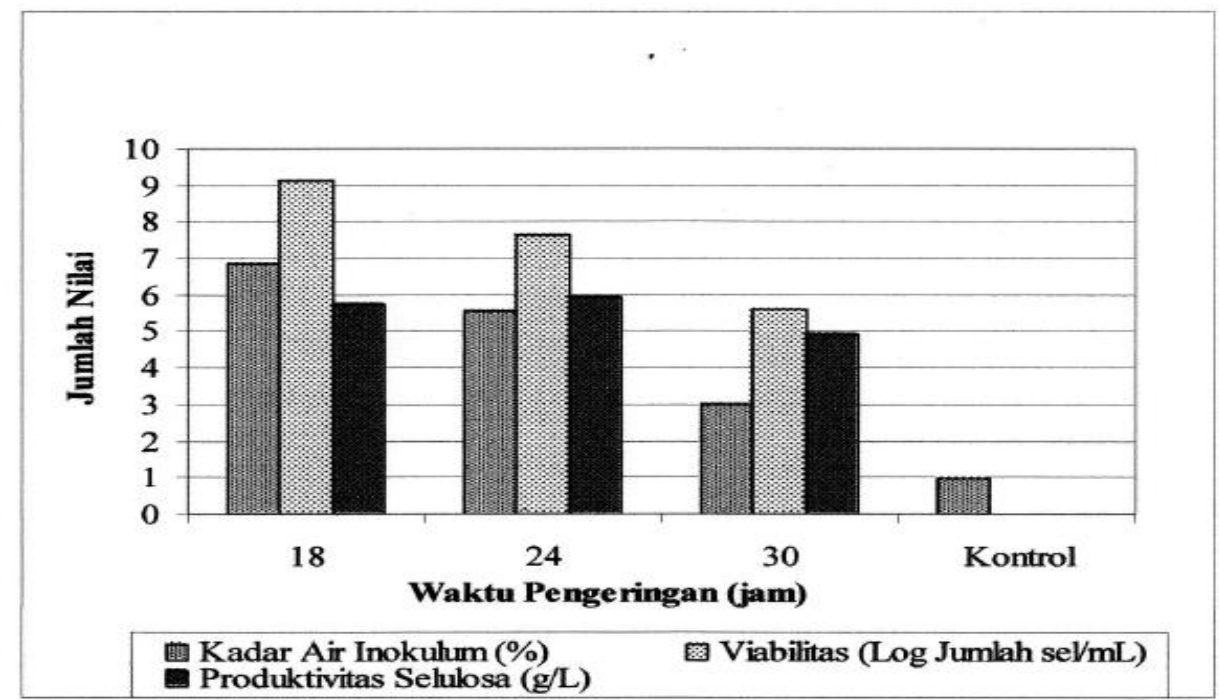

Gambar IV.11. Diagram nilai kadar air dan viabilitas inokulum hasil optimisasi waktu pegeringan inokulum dengan substrat pembawa berupa serbuk ampas kelapa parut kering serta produktivitas selulosanya. Suhu pengeringan $30^{\circ} \mathrm{C}$ dan perbandingan substrat pembawa - $\quad 1: 2$. Kontrol berupa serbuk ampas kelapa parut kering tanpa inokulum.

Pengeringan inokumum pada suhu $30^{\circ} \mathrm{C}$ dengan perbandingan substrat pembawa dengan inokulum cair 1:2 dioptimasi waktunya yaitu pada 18, 24 dan 30 jam. Hasil optimasi tersebut menunjukkan bahwa waktu pengeringan 30 jam menghasilkan inokulum kering yang paling baik. Inokulum dengan substrat pembawa berupa serbuk kelapa parut memiliki kadar air rendah yaitu 3,25\% dengan vabilitas sel $1,0 \times 10^{7} \mathrm{sel} / \mathrm{g}$ dan produktivitas selulosa 5,55 g/L. Sedangkan inokulum dengan substrat pembawa berupa serbuk ampas kelapa memiliki kadar air 2,98\%, viabilitas $4,2 \times 10^{5} \mathrm{sel} / \mathrm{g}$ dan produktivitas selulosanya sebasar 4,92 g/L. Produktivitas selulosa inokulum kering tersebut hanya mengalami penurunan sebesar $9,7 \%$ dan 20 $\%$ dari produktivitas selulosa hasil inokulum cair dari isolat $A$. xylinum asal yaitu $6,15 \mathrm{~g} / \mathrm{L}$.

Salah satu hal yang diduga sebagai zat yang berpengaruh dalam pembentukan selulosa adalah kandungan minyak yang terdapat pada serbuk kelapa parut kering. Serbuk kelapa parut kering memiliki kadar minyak sekitar $65 \%$ dari total beratnya (Palungkun, 2004). Sedangkan serbuk ampas kelapa parut kering memiliki kadar minyak yang lebih rendah karena kandungan minyak sudah banyak hilang pada saat pengambilan santannya. Kandungan minyak yang terkandung dalam serbuk tidak akan terlarut dalam air dan akan berada pada permukaan medium cair fermentasi. Hal tersebut kemungkinan dapat berpengaruh terhadap kontak sel-sel $A$. xylinum dengan udara di permukaan medium fermentasi.

\section{KESIMPULAN}

1. Inokulum dalam bentuk serbuk kering dengan substrat pembawa berupa serbuk kelapa parut dan serbuk ampas kelapa parut dapat dibuat dengan pengeringan suhu $30^{\circ} \mathrm{C}$ selama 30 jam dengan perbandingan substrat pembawa : inokulum cair sebesar $1: 2$.

2. Inokulum kering dengan substrat pembawa berupa serbuk kelapa parut memiliki kadar air $3,25 \%$, vabilitas $1,0 \quad$ x $10^{7} \quad \mathrm{sel} / \mathrm{g}$ dan produktivitas selulosa $5,55 \mathrm{~g} / \mathrm{L}$.

3. Inokulum kering dengan substrat pembawa berupa serbuk ampas kelapa parut memiliki kadar air 2,98\%, viabilitas 4,2 x $10^{5} \mathrm{sel} / \mathrm{g}$ dan produktivitas selulosanya sebasar 4,92 g/L.

4. Produktivitas selulosa inokulum kering tersebut setara dengan $80 \%$ produktivitas selulosa hasil inokulum cair dari isolat $A$. xylinum asal.

\section{DAFTAR PUSTAKA}

Fardiaz, S. 1992. Teknologi Pengawetan Kulktur Nata Untuk Pengembangan Industri Nata Dari Berbagai Limbah Pertanian. Fakultas Teknologi Pangan IPB, Bogor : xi + 66 hlm.

Lapuz, M.M., Gallardo, E.G.\& Palo, M.A.,1967. The Nata Organism-Cultural Requirements, characteristics and Identity. Philippine Jurnal Of Sience. 96 (2) : 91-111.

Parton C.\& P. Willis. 1990. Strain Preservation, Inoculum Preparation and Inoculum Development. Press Oxford University Press

Palungkun, R., 2004, Aneka Produk Olahan Kelapa, Penebar Swadaya, Jakarta

Serafica, G. C., 1997. Production Of Bacterial Cellulose Using a Rotating Disk Film 
Bioreactor by Acetobacter xylinum, $\mathrm{PhD}$ Thesis, Rensselaer Polytechnic institute

Sudirjo, S. T., 1996. Selulosa Bakteri Sebagai Alternatif Sumber Serat. Berita selulosa 32 (3): 20-25.
Waspodo, P.,A. Budiono \& N. Sujono. 2000. Viability of dried starters of Acetobacter xylinum and their yields of bacterial cellulose. Dalam : 2000. Proceding of The Second International Workshop on Green Polymers. Bandung - Bogor : 348- 351 